\title{
Digestive Morphology of Native Pig Supplemented by Different Levels of Fermented Vigna radiata $L$.
}

\author{
Ken N Falculan Ph.D. \\ Assistant Professor, Animal Science Department, College of Agriculture Romblon State University, Odiongan, Romblon
}

\begin{abstract}
Enhancing feed efficiency in converting feed mass into pig body mass is a critical phase for the profit in producing pig. To improve the metabolic utilization of dietary nutrients, it relies heavily on a healthy gut or gastrointestinal tract, and only a healthy digestive can result in better feed digestion and better nutrient absorption. Thus, the study investigates the growth performance, the response of the digestive morphology of native pigs, which treatment will stretch higher output and variations under different levels of fermented mungbean. The experimental research design was employed to determine the response of the three (3) pigs treated with mungbean for 70 days. The growth performance of pigs treated with different levels of fermented mungbean has a total gain weight of $7.50 \mathrm{~kg}$ for Treatment 1 ; Treatment 2 is $9.00 \mathrm{~kg}$ and, Treatment 3 is $6.50 \mathrm{~kg}$ and is observed no significant difference on the final weight and the total weight with a p-value of $>0.050$; the response on digestive morphology such as small intestine, large intestine, heart, stomach, liver, lungs, esophagus, spleen, and kidney of pigs shows no variations on their length, width, and weight with a p-value of $>0.050$ under the different level of fermented mungbean; and resulted with high output treated with different level of fermented mungbean is observed on Treatment 2 with a lowest feed conversion efficiency of 3.89 for feeds and 1.39 for mungbean. Treatment 2 has the highest gain weight among the treated sample; the intestinal morphology of pigs was comparable under the three treatments; treatment 2 has the lowest feed conversion efficiency.
\end{abstract}

KEYWORDS: Digestive Morphology, Dietary Treatment, Fermentation, Growth Performance, Metabolic Utilization

\section{INTRODUCTION}

Feed efficiency represents the cumulative efficiency with which the pig utilizes dietary nutrients for maintenance, lean gain, and lipid accretion. The less efficient utilization of feed with a low protein diet in the modern pig husbandry will have to enhance the feeding diet to a plant-based diet containing complex protein and carbohydrates includes various antinutritional factors (Baguio, 2017). Weaning imposes tremendous stress on piglets and is accompanied by marked changes in gastrointestinal physiology, microbiology, and immunology. The period following weaning is characterized by a high incidence of intestinal disturbance with diarrhea and depression of growth performance of piglets. Poor growth performance associated with weaning in piglets is a result of multifactorial stressors including environmental, nutritional, physiological stressors. At weaning, pigs have to deal with the abrupt interruption in the established social interaction with sow and litter and the stress of adapting to a new environment. The piglet has to cope with the sudden withdrawal of sow milk and adapt to; less digestible, plant-based dry diets containing complex protein and carbohydrates including various antinutritional factors (Heo et al., 2012). In modern pig husbandry, piglets are forcibly weaned at 3 to 4 weeks of age, which is much shorter than that in the natural suckling habitat of approximately 8 to 12 weeks of nursing. Early weaning of pigs resulted in increased expression of genes related to oxidative stress and immune activation but decreased expression of genes related to macronutrient metabolism and cellular proliferation in the gut (Lee et al., 2016). Mungbean is a warm-season annual highly branched having trifoliate leaves like the other legumes. The plant upright and vine types of growth habit occur in it, with plants varying from one to five feet in length (Wu et al., 2019). Fermentation is the conversion of carbohydrates to alcohol and carbon dioxide or organic acids using yeast, bacteria, or a combination, under anaerobic conditions without net oxidation. It enhances nutrition, stabilization of the original raw materials, and detoxification and antinutritional factors. Fermentation can also increase the soluble phenolic content of legumes and consequently elevate their antioxidant activities (John and Olusegun, 2016). Lactic acid bacteria are a group of microorganisms were colonized in the intestine and exert beneficial health effects on human and animal bodies. The well- known; "generally recognized as safe" status and the probiotic role of the lactic acid bacteria has resulted; in an increased awareness of developing functional foods by using these strains. Apart from traditional fermented dairy products such as 


\section{International Journal of Current Science Research and Review}

ISSN: 2581-8341

Volume 04 Issue 11 November 2021

DOI: 10.47191/ijesrr/V4-i11-13, Impact Factor: 5.825

IJCSRR@ 2021

www.ijesrr.org

yogurt and cheese, specific lactic acid bacteria strains were also introduced to plant origin foodstuffs among which soy and soymilk were exploited most widely (Rui et al., 2015).

\section{MATERIALS AND METHODS}

\section{Methodology}

The experimental design was applied to determine the response of weaning impacts in digestive morphology fed with different levels of mungbean meal and fermented mungbean as a feed supplement. Completely Randomized Design was used; were in, in the experiment involves determining treatments; treatment 1 , commercial feeds, Treatment $2 \& 3$ mungbean meal, fermented mungbean meal, and commercial feeds.

\section{Population and Sample of the Study}

The population of the study were three native pigs ( 3 months old) randomly assigned to three dietary treatments.

\section{Materials}

The following materials and equipment were used in the identifying the morphology of pigs through experimental method: three (3) heads of native pigs ( 3 months old), commercial feeds (trigo), mungbean meal (cooked), fermented mungbean, distilled water, 1 tablespoon of salt for every cup of water, weighing scale, plastic jar, brine, measuring cups, morphometry / tape measure, caliper, record book and ballpen.

\section{Experimental design}

Completely randomized design was used in the experiment which involves three treatments with no replications using 3 heads of pigs. Every treatment was composed of 1 heads of experimental pig as represented by T1 commercial feeds; T2 and T3 mungbean meal, fermented mungbean meal and commercial feeds. Treatments-(levels of mungbean meals), Treatment 1 - control 1000 grams commercial feeds, Treatment 2 - 500 grams commercial feeds +250 grams mungbean meal +250 grams fermented mungbean, Treatment 3 - 500 grams commercial feeds +300 grams mungbean meal +200 grams fermented mungbean (Figure 1).

Figure 1. The distribution of treatments shown in the experimental layout.

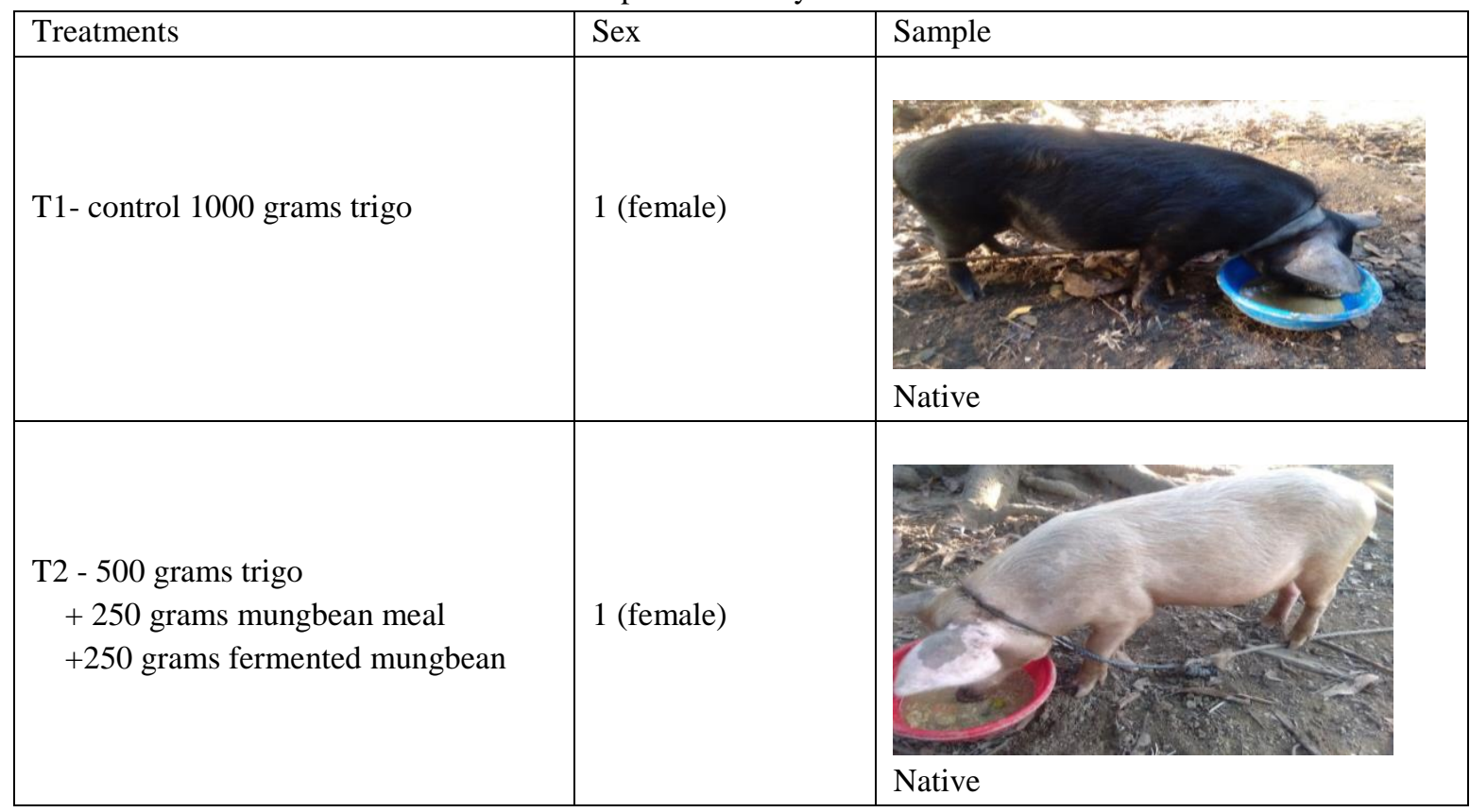




\section{International Journal of Current Science Research and Review}

ISSN: 2581-8341

Volume 04 Issue 11 November 2021

DOI: 10.47191/ijesrr/V4-i11-13, Impact Factor: 5.825

\begin{tabular}{|l|l|l|}
\hline $\begin{array}{l}\text { T3- } 500 \text { grams trigo } \\
+300 \text { grams mungbean meal } \\
+200 \text { grams fermented mungbean }\end{array}$ & 1 (male) & \\
& & \\
\hline Total & 3 Heads & \\
\hline
\end{tabular}

\section{Procedure}

This includes the procedure in the conduct of the experimental study such as; construction of experimental cage, cleaning and disinfecting of the experimental area, selection and purchase of experimental animal, feeds/ biological and feed supplement, feed preparation, feeding and water management, dressing of pig, data collection and statistical treatment of data.

\section{Data Gathering}

The data was collected right after the slaughtering of experimental animals on the different level of treatments. The data gathered on the growth performance of pigs in terms of weight using the hanging scale while the intestinal morphology and digestive tract; small intestine, large intestine, spleen, stomach, Liver, lungs, esophagus and kidney was measured by its length, width and weight using the morphometric equipment/tape measure/caliper. After the data had been gathered it was recorded and described.

\section{RESULTS AND DISCUSSION}

Results shows Table 1, the coefficient of determination r-square (r2) of 0.182 using the linear regression implies that $18.20 \%$ of the variation in the gain in weight of pigs is explained by the different levels of treatment. Based on the different level of treatment it can be viewed that Treatment 2 obtained the highest final body weight of 30 kilos with a gain weight of 9 kilos with an initial body weight of 21 kilos feeding with 500 grams of commercial feeds, 250 grams of mungbean meal and 250 grams of fermented mungbean compared to Treatment 1 which has a final body weight of 28 kilos with a total gain weight of 7.50 kilos from the initial body weight of 20.50 feeding with 1000 grams of commercial feeds; while Treatment 3 has the lowest final body weight of 27 kilos with total gain weight of 6.50 kilos from the initial body weight of 20.50 kilos feed with 500 grams commercial feeds, 300 grams mungbean meal and 200 grams of fermented mungbean. The treatment was given to the pig's daily morning and afternoon. It can be said that Treatment 2 can be used as predictors of the growth performance of pigs. Further, the analysis shows that it is $95 \%$ confident that the slope of the true regression line is somewhere -20.924 and 19.424 on the total gain weight and -18.840 and 17.840 on the final gain weight. This means that for every treatment the pig's intake, the average estimated cost spent for every treatment increases somewhere between Php18.840 and Php17.840 and Php20.924 and Php19.424 respectively. At the 5\% level of significance, it can be concluded that the gain in weight regression line with a computed F-value of .000 for initial body weight, .120 for final body weight and .223 for the total gain weight were shown by its p-value of $>0.050$ has no significant difference. Hence, the result of the null hypothesis of the three treatments on the growth performance of pigs is accepted and therefore useful as a predictor of the weights of pigs. From the above coefficients, the regression equation can be computed as, final body weight = $29.333-.500$ (treatment) and the total gain weight is $20.667+0.000$ (treatment) $=20.667$. The result on the growth performance of native pigs may be attributed to the short experimental period and further morphological changes may occur over a more extended period. It can be noted that, there were only marked breed difference on the growth of pigs ranges from 1.50-2.50 kilos which supports the hypothesis that the growth performance is not significantly affected by the different levels of treatment. The potential of fermented liquid feed is an alternative to be use on growth promoting antibiotic in the pig diet (Missoten, 2015). 


\section{International Journal of Current Science Research and Review}

ISSN: 2581-8341

Volume 04 Issue 11 November 2021

DOI: 10.47191/ijesrr/V4-i11-13, Impact Factor: 5.825

IJCSRR@ 2021

www.ijesrr.org

Table 1. Growth performance of pigs treated with different level of fermented mungbean in the diet

\begin{tabular}{|c|c|c|c|}
\hline & Body weight $(\mathrm{N}=3)$ & & \\
\hline Treatment & $\begin{array}{l}\text { Initial body weight } \\
\text { (in } \mathrm{kg} \text { ) }\end{array}$ & $\begin{array}{l}\text { Final body weight } \\
\text { (in } \mathrm{kg} \text { ) }\end{array}$ & $\begin{array}{l}\text { Total gain weight } \\
\text { (in } \mathrm{kg} \text { ) }\end{array}$ \\
\hline $\mathrm{T}_{1}$ & 20.50 & 28.00 & 7.50 \\
\hline $\mathrm{T}_{2}$ & 21.00 & 30.00 & 9.00 \\
\hline $\mathrm{T}_{3}$ & 20.50 & 27.00 & 6.50 \\
\hline R square & .000 & .107 & .182 \\
\hline p-value & 1.000 & .788 & 0.719 \\
\hline $\mathrm{F}$ & .000 & .120 & .223 \\
\hline \multicolumn{4}{|c|}{ Unstandardized coefficients: } \\
\hline (Constant) & 20.667 & 29.333 & 9.167 \\
\hline Treatment & .000 & -.500 & -.750 \\
\hline \multicolumn{4}{|c|}{ 95.0\% Confidence Interval for B: } \\
\hline Lower Bound & -3.668 & -18.840 & -20.924 \\
\hline Upper Bound & 3.668 & 17.840 & 19.424 \\
\hline Interpretation & Not Significant & Not Significant & Not Significant \\
\hline
\end{tabular}

The response of intestinal morphology of pigs (Table 2) in terms of small intestine treated with different level of feeding regimen. The result of analysis on the table shows that, the coefficient determination of r-square ( $\mathrm{r} 2)$ on the length (0.885), width (0.429) and weight ( 0.250 ) of pigs indicates that, $88.50 \%$ (length), $42.90 \%$ (width) and $25.00 \%$ (weight) of the variations in the small intestine of pigs is observed on the different levels of treatment. The $95 \%$ confidence interval states that the slope of the regression line is somewhere between -223.398 and 143.398 on the length, -1.567 and 1.367 on the width and -575.195 and 525.195 on the weight of small intestine. This implies that for every treatment the pig's intake to gain weight, their estimated average cost consumed increases somewhere in between Php575.195 and 525.195. At the significance level of 5\%, it can be observed that the length (.220), width (.546) and weight (.667) of small intestine of pig regression line is shown by its p-value $>0.050$. Thus, the length, width and weight of small intestine are significantly not different regardless of treatment. It can now conclude that the hypothesis is accepted and the different levels of treatment are useful predictors on the growth performance of pigs. From the above coefficients, the regression equation can be computed as, Length of small intestine $=1231.667-40.000$ (Treatment) $=1191.667 ;$ width $=1.067-0.100$ $($ treatment $)=0.967$; and weight $=800.000-25.000$ (treatment $)=775.000$. It was observed on Treatment 2 that the small intestine has the highest kilograms of 800 treated with 500 grams of commercial feeds, 250 grams of mungbean meal and 250 grams fermented mungbean. Likewise, Treatment 1 and Treatment 3 has 50 kilograms decrease in weight which is 750 grams and 700 grams respectively treated with the same amount of commercial feeds but differ in mungbean meal and fermented mungbean intakes. The small intestine is the major site of nutrient digestion and absorption wherein the intestinal epithelium, gut associated lymphatic lymphoid tissues, and the gut microbiota play crucial roles in the prevention of pathogenic microorganisms, toxins, and allergenic macromolecules from entering the interior space of the body and the maintenance of the gastrointestinal tract (GIT) homeostasis (Gao 2013). That is why, the higher levels of Lactobacillus in the total bacteria population, the higher ratio of Lactobacillus to E. coli, the higher mRNA levels of tight junction proteins in the pigs with and without challenge. Therefore, it is assumed that the pigs may possess a better ability to maintain the intestinal physiology homeostasis. 


\section{International Journal of Current Science Research and Review}

ISSN: 2581-8341

Volume 04 Issue 11 November 2021

DOI: 10.47191/ijesrr/V4-i11-13, Impact Factor: 5.825

IJCSRR@ 2021

www.ijjcsrr.org

Table 2. Response of intestinal morphology (small intestine) of pigs treated with different level of fermented mungbean in the diet

\begin{tabular}{llll}
\hline \hline \multirow{2}{*}{ Treatment } & \multicolumn{2}{l}{ Small Intestine } & \\
\cline { 2 - 4 } & $\begin{array}{l}\text { Length } \\
\text { (in cm) }\end{array}$ & $\begin{array}{l}\text { Width } \\
\text { (in cm) }\end{array}$ & $\begin{array}{l}\text { Weight } \\
\text { (in kgs) }\end{array}$ \\
\hline $\mathrm{T}_{1}$ & 1200 & 0.9 & 750 grams \\
$\mathrm{T}_{2}$ & 1135 & 1 & 800 grams \\
$\mathrm{T}_{3}$ & 1120 & 0.7 & 700 grams \\
\hline $\mathrm{R}$ square & .885 & .429 & .250 \\
$\mathrm{p}$-value & .220 & .546 & .667 \\
$\mathrm{~F}$ & 7.680 & .750 & .333 \\
Unstandardized coefficients: & & \\
$\quad$ (Constant) & 1231.667 & 1.067 & 800.000 \\
$\quad$ Treatment & -40.000 & -.100 & -25.000 \\
95.0\% Confidence Interval for B: & & \\
$\quad$ Lower Bound & -223.398 & -1.567 & -575.195 \\
$\quad$ Upper Bound & 143.398 & 1.367 & 525.195 \\
\hline Interpretation & Not Significant & Not Significant & Not Significant \\
\hline \hline
\end{tabular}

Represented on Table 3, the length, width and weight of the large intestine of pigs treated with different level of fermented mungbean in the diet. As observed on the table, the coefficient determination r-square (r2) of the intestinal morphology of pigs in terms of length (.824) and weight and width (.964) of the large intestine shows that, $82.4 \%$ of length and weight and $96.4 \%$ of width was influence by the different levels of treatment. The $95 \%$ confidence interval of the length is somewhere -137.375 and 97.375 , width is somewhere -.517 and .217 , and the weight of the large intestine is somewhere -3434.372 and 2434.372.

This implies that, for every treatment the pig's intake, the average estimated cost spent to gain a kilo of intestine is somewhere between Php3434.372 and Php2434.372. At the significance level of 5\%, the large intestine is statistically no variations as shown by its p-value $>0.050$ on length (.275), width (.121) and weight (.275). Therefore, the null hypothesis is accepted and the treatment is useful predictors on the weight of pigs. From the above coefficients, the regression equation can be computed as, length of large intestine $=464.667-20.000$ (treatment $)=444.667$, width $=2.167-.150=2.017$, and weight $=2866.667-500.000$ (treatment) $=$ 2366.667. As observed, Treatment 1 has the highest weight of 2500 grams treated with 100 percent of commercial feeds while the slight decrease on weight of Treatment 2 and Treatment 3 is due to the same amount of feeds intakes which is 500 grams commercial feeds and different grams of mungbean meal and fermented mungbean resulted to a total weight of 1600 and 1500 grams respectively. The weight variations of Treatment 1 ranges from 900 grams to 1000 grams is due to the waste materials found inside the large intestine. Relatively, the four diets fed such as basal corn-soybean meal (B), 15\% oat hulls (OH), 15\% soybean hulls ( $\mathrm{SH})$, and $20 \%$ alfalfa meal (AM) did not have major effects on performance in a 35-d feeding trial. Balance trials (7-d duration) were conducted $32 \mathrm{~d}$ (Trial 1) or $6 \mathrm{~d}$ (Trial 2) after completion of the feeding trials. Feed intakes were equalized at $8.7 \%$ (Trial 1 ) or $10.3 \%$ (Trial 2) of initial body weight kg.75 (Moore 1988). All fiber sources decreased apparent digestibility's of N, energy and dry matter $(\mathrm{P}<.05)$ with no effect on $\mathrm{N}$ retention. Hence, the fiber sources at the levels included in a corn-soybean meal diet fed in this study had only a minimal impact on performance and utilization of minerals and $\mathrm{N}$ and intestinal structure, although apparent energy utilization was decreased.

Table 3. Response of intestinal morphology (large intestine) of pigs treated with different level of fermented mungbean in the diet.

\begin{tabular}{llll}
\hline \hline \multirow{2}{*}{ Treatment } & Large Intestine & \\
\cline { 2 - 4 } & Length (in cm) & Width (in cm) & Weight (in kg) \\
\hline $\mathrm{T}_{1}$ & 450 & 2 & $2,500 \mathrm{~g}$ \\
$\mathrm{~T}_{2}$ & 414 & 1.9 & $1600 \mathrm{~g}$ \\
$\mathrm{~T}_{3}$ & 410 & 1.7 & $1500 \mathrm{~g}$ \\
\hline \hline
\end{tabular}




\section{International Journal of Current Science Research and Review}

ISSN: 2581-8341

Volume 04 Issue 11 November 2021

DOI: 10.47191/ijesrr/V4-i11-13, Impact Factor: 5.825

IJCSRR@ 2021

www.ijesrr.org

\begin{tabular}{llll}
\hline R square & .824 & .964 & .824 \\
p-value & .275 & .121 & .275 \\
F & 4.688 & 27.000 & 4.688 \\
Unstandardized Coefficients: & & & \\
$\quad$ (Constant) & 464.667 & 2.167 & 2866.667 \\
$\quad-20.00$ & -.150 & -500.000 \\
$\quad$ Treatment & & & \\
95.0\% Confidence interval for B: & -137.375 & -.517 & -3434.372 \\
$\quad$ Lower Bound & 97.375 & .217 & 2434.372 \\
$\quad$ Upper Bound & Not Significant & Not Significant & Not Significant \\
\hline 'Interpretation & & & \\
\hline
\end{tabular}

Response of intestinal morphology (heart) of pigs (Table 4) treated with different level of fermented mungbean in the diet. As shown on the table, the coefficient determination $\mathrm{r}$-square ( $\mathrm{r} 2)$ of the intestinal morphology of pigs in terms of the length of the heart (.750), width (.750) and weight (.250) shows that, $75 \%$ of length and width and $25 \%$ of weight was explained by the different levels of treatment. The $95 \%$ confidence interval in the length of the heart is somewhere -4.168 and 3.168, width is somewhere -3.334 and 2.534 and the weight is somewhere -575.195 and 525.195 . This means that, for every treatment the pig's intake, the estimated average cost consumed to gain a kilo of the heart is somewhere in between Php575.195 and Php525.195. At the significance level of $5 \%$, the large intestine is statistically no variations as shown by its p-value $>0.050$ on length (.333), width (.333) and weight (.667). Therefore, the null hypothesis is accepted and the treatment is useful predictors on the growth performance of pigs. From the above coefficients, the regression equation can be computed as, length of heart $=9.333-.500$ (treatment) $=8.833$, width $=5.567$ -.400 (treatment) $=5.167$, and weight $=200.000-25.000$ (treatment $)=175.000$. The analysis further indicates that, the 50 grams variations on weight among the three treatments is observed on Treatment 2 with a total weight of 200 grams treated with 500 grams commercial feeds, 250 grams mungbean meal and 250 grams fermented mungbean. Treatment 1 and Treatment 2 have the same weight of 150 grams which means that the feeds intakes having the same amount of commercial feeds but differ in mungbean meal and fermented mungbean implies no variations on the weight of the heart. In adding organic acids to piglet diets is known to be helpful in overcoming post-weaning syndrome, and butyric acid is the main energy source for the epithelial cells of the large intestine and the terminal ileum (Biagi et al, 2007). However, Sodium butyrate did not improve the animal growth performance. In the cecum, Sodium Butyrate increased $\mathrm{pH}$ and isobutyric acid concentration (linear, $\mathrm{P}<0.05$ ) and tended to increase ammonia concentration $(\mathrm{P}=0.056)$. Intestinal counts of clostridia, Enterobacteriaceae, and lactic acid bacteria as well as intestinal mucosal morphology were not affected by feeding Sodium Butyrate.

Table 4. Response of intestinal morphology (heart) of pigs treated with different level of fermented mungbean in the diet.

\begin{tabular}{|c|c|c|c|}
\hline \multirow[b]{2}{*}{ Treatment } & \multicolumn{3}{|l|}{ Heart } \\
\hline & Length (in $\mathrm{cm}$ ) & Width (in $\mathrm{cm}$ ) & Weight (in kg) \\
\hline $\mathrm{T}_{1}$ & 8 & 4.5 & 150 grams \\
\hline $\mathrm{T}_{2}$ & 9 & 5.3 & 200 grams \\
\hline $\mathrm{T}_{3}$ & 8 & 4.5 & 150 grams \\
\hline R square & .750 & .750 & .250 \\
\hline p-value & .333 & .333 & .667 \\
\hline $\mathrm{F}$ & 3.000 & 3.00 & .333 \\
\hline \multicolumn{4}{|c|}{ Unstandardized Coefficient: } \\
\hline (Constant) & 9.333 & 5.567 & 200.000 \\
\hline Treatment & -.500 & -.400 & -25.000 \\
\hline \multicolumn{4}{|c|}{$95.0 \%$ Confidence Interval for B: } \\
\hline Lower Bound & -4.168 & -3.334 & -575.195 \\
\hline Upper Bound & 3.168 & 2.534 & 525.195 \\
\hline Interpretation & Not Significant & Not Significant & Not Significant \\
\hline
\end{tabular}




\title{
International Journal of Current Science Research and Review
}

\author{
ISSN: 2581-8341
}

Volume 04 Issue 11 November 2021

DOI: 10.47191/ijcsrr/V4-i11-13, Impact Factor: 5.825

It is observed on Table 5, the response of stomach of pigs treated with different level of fermented mungbean in the diet. The coefficient determination of $\mathrm{r}$-square ( $\mathrm{r} 2)$ is 0.000 on the length, width and weight of stomach of pigs. This implies that, a dropped to zero of $\mathrm{r} 2$ means that, $0 \%$ indicates that there is no linear relation between the length of the stomach, width and weight of pigs under the different treatment. The $95 \%$ confidence interval in the length of the heart is somewhere +7.336 , width is +4.402 , and weight is somewhere +733.593 . This indicates that, for every treatment the pig's intake, the estimated average cost spent to gain the weight of the stomach is somewhere in between Php733.93. At the significance level of 5\%, the length, width and weight of the stomach had no variations as shown by its p-value $>0.050$ which is 1.000 . Therefore, the null hypothesis is accepted. From the above coefficients, the regression equation can be computed as, length of stomach $=23.333+0.000$ (treatment), width $=11.100+$ 0.000 (treatment) and weight $=683.333+0.000$ (treatment). The result of analysis further observed that Treatment 2 got the highest total weight of 750 grams treated with 500 grams commercial feeds, 250 grams mungbean meal and 250 grams fermented mungbean compared to Treatment 1 treated with 100 percent commercial feeds and Treatment 3 treated with 500 grams commercial feeds and 300 grams mungbean meal and 200 grams of fermented mungbean with a slight decrease in weight of 50 grams respectively. Piglets fed with Fermented Soybean Meal had a higher $(\mathrm{P}<0.05)$ villus height at three different locations of small intestine and had a lower $(\mathrm{P}<0.05)$ crypt depth in the duodenum compared to piglets fed SBM (Feng et al., 2007). The results showed that activities of total protease and trypsin at the duodenum and jejunum of piglets fed with Fermented Soybean Meal increased $(\mathrm{P}<0.05)$ compared with the control. The trypsin activity in the pancreas of piglets decreased $(\mathrm{P}<0.05)$ when they were fed with FSBM. The results showed that FSBM improved intestinal morphology and digestive enzyme activities in weaned piglets.

Table 5. Response of intestinal morphology (stomach) of pigs treated with different level of fermented mungbean in the diet.

\begin{tabular}{|c|c|c|c|}
\hline \multirow[b]{2}{*}{ Treatment } & \multicolumn{3}{|c|}{ Stomach } \\
\hline & $\begin{array}{l}\text { Length } \\
\text { (in } \mathrm{cm} \text { ) }\end{array}$ & $\begin{array}{l}\text { Width } \\
\text { (in } \mathrm{cm} \text { ) }\end{array}$ & $\begin{array}{l}\text { Weight } \\
\text { (in kg) }\end{array}$ \\
\hline $\mathrm{T}_{1}$ & 23 & 10.9 & 650 grams \\
\hline $\mathrm{T}_{2}$ & 24 & 11.5 & 750 grams \\
\hline $\mathrm{T}_{3}$ & 23 & 10.9 & 650 grams \\
\hline $\mathrm{R}$ square & .000 & .000 & .000 \\
\hline p-value & 1.000 & 1.000 & 1.000 \\
\hline $\mathrm{F}$ & .000 & .000 & .000 \\
\hline \multicolumn{4}{|c|}{ Unstandardized Coefficient: } \\
\hline (Constant) & 23.333 & 11.100 & 683.333 \\
\hline Treatment & .000 & .000 & .000 \\
\hline \multicolumn{4}{|c|}{$95.0 \%$ Confidence Interval for B: } \\
\hline Lower bound & -7.336 & -4.402 & -733.593 \\
\hline Upper bound & 7.336 & 4.402 & 733.593 \\
\hline
\end{tabular}

Table 6 presents the response of intestinal morphology of pigs in relation to liver treated with different level of fermented mungbean in the diet. As observed on the table, the coefficient determination r-square of length (.250), width (.250) and weight (.107) of pigs implies that $25 \%$ of the variations of the length and width and $10.70 \%$ of the weight of liver are explained by the different level of treatment. The $95 \%$ confidence interval shows that, the length of the liver is somewhere -5.752 and 5.252, width is somewhere 5.752 and 5.252, and the weight is somewhere -376.797 and 356.797. This implies that, for every treatment the pigs consumed, the estimated average cost to be spent to gain a kilo of liver is somewhere in between Php376.797 and Php356.797. At the significance level of 5\%, the length, width and weight of the liver had no variations as shown by its p-value $>0.050$ which is .667 for length and width and .788 for weight. Thus, the null hypothesis is accepted. From the above coefficients, the regression equation can be computed as, length of liver $=26.500-0.250$ (treatment), width $=19.100-0.250$ (treatment) and weight $=746.667-10.000$ (treatment). It is also implied on the table that Treatment 2 obtained the highest total weight of 760 grams treated with 500 grams commercial feeds, 250 grams of mungbean meal and fermented mungbean, followed by Treatment 1 with a total weight of 720 grams treated with 100 percent commercial feeds and the lowest total weight of 700 grams was observed on Treatment 3 which is 


\section{International Journal of Current Science Research and Review}

ISSN: 2581-8341

Volume 04 Issue 11 November 2021

DOI: 10.47191/ijcsrr/V4-i11-13, Impact Factor: 5.825

treated with 500 grams commercial feeds and 300 grams and 200 grams of mungbean meal and fermented mungbean respectively. Thus, it only shows that the different level of treatment can be used as predictors of growth performance of pigs especially on Treatment 2. The effect of fiber source and concentration on morphological characteristics, mucin staining pattern, and mucosal enzyme activities in the gastrointestinal tract of pigs using 50 experimental 50 weaned pigs treated with 10 litters at 4 weeks of age (BW $8.6 \pm 1.4 \mathrm{~kg}$ ) and divided into 5 treatment groups with diets containing fiber of various physico-chemical properties and concentrations were formulated to contain 73, 104, or $145 \mathrm{~g}$ of dietary fiber/kg of DM (Hedemann et al., 2006). Feeding pigs high insoluble fiber diets improved gut morphology by increasing villi length and increased mucosal enzyme activity when compared with pigs fed pectin-containing diets. The mucin content as determined by staining characteristics suggests that pigs fed high insoluble fiber diets might be better protected against pathogenic bacteria than pigs fed diets high in soluble fiber.

Table 6. Response of intestinal morphology (liver) of pigs treated with different level of fermented mungbean in the diet.

\begin{tabular}{|c|c|c|c|}
\hline \multirow[b]{2}{*}{ Treatment } & \multicolumn{3}{|l|}{ Liver } \\
\hline & $\begin{array}{l}\text { Length } \\
\text { (in } \mathrm{cm} \text { ) }\end{array}$ & $\begin{array}{l}\text { Width } \\
\text { (in } \mathrm{cm} \text { ) }\end{array}$ & $\begin{array}{l}\text { Weight } \\
\text { (in kg) }\end{array}$ \\
\hline $\mathrm{T}_{1}$ & 26 & 18.5 & 720 grams \\
\hline $\mathrm{T}_{2}$ & 26.5 & 19 & 760 grams \\
\hline $\mathrm{T}_{3}$ & 25.5 & 18 & 700 grams \\
\hline R square & .250 & .250 & .107 \\
\hline p-value & .667 & .667 & .788 \\
\hline $\mathrm{F}$ & .333 & .333 & .120 \\
\hline \multicolumn{4}{|c|}{ Unstandardized Coefficient: } \\
\hline (constant) & 26.500 & 19.000 & 746.667 \\
\hline Treatment & -.250 & -.250 & -10.000 \\
\hline \multicolumn{4}{|c|}{$95.0 \%$ Confidence interval for B: } \\
\hline Lower bound & -5.752 & -5.752 & -376.797 \\
\hline Upper bound & 5.252 & 5.252 & 356.797 \\
\hline Interpretation & Not Significant & Not Significant & Not Significant \\
\hline
\end{tabular}

It can be seen on Table 7, the response of intestinal morphology of pigs in terms of lungs treated with fermented mungbean in the diet. As shown on the table, the coefficient determination of r-square (r2) is 0.001 on the length, width (.107) and weight (.158) of lungs of pigs. This means that, $1.00 \%$ of the variations of length, $10.7 \%$ of the variations of width and $15.8 \%$ of weight of the lungs are explained by the different level of treatment. The $95 \%$ confidence interval in the length of the lungs is somewhere -79.428 and 79.028, width is -18.840 and 17.840 , and weight is somewhere -303.437 and 283.437 . This indicates that, for every treatment the pig's intake, the estimated average cost of the weight of the lungs spent is somewhere in between Php303.437 and Php283.437. At the significance level of 5\%, the length, width and weight of the lungs has no significant difference as shown by its p-value $>0.050$ wherein the p-value of length is $.980, .788$ for width and .740 for weight. Thus, the null hypothesis is accepted. From the above coefficients, the regression equation can be computed as, length of lungs $=19.800-.200$ (treatment), width $=10.333-0.500$ (treatment) and weight $=343.333-10.000$ (treatment). The result of analysis further indicates that, Treatment 2 obtained the highest total weight of 350 grams compared to Treatment 1 and Treatment 2 with a total weight of 320 grams and 300 grams respectively. The result emphasizes that the slight increase or decrease of weight in grams is due to the influence of different treatments given to pigs daily. Hence, it is observable that weight of pigs in terms of lungs can be predicted by the different level of mungbean intakes. Additional benefits from liquid feeding include an increase in nutrient digestibility, improved intestinal morphology, a reduction in the content of various anti-nutritional factors in feeds and a reduction in dust levels in swine barns (Missoten et al., 2015). 


\section{International Journal of Current Science Research and Review}

ISSN: 2581-8341

Volume 04 Issue 11 November 2021

DOI: 10.47191/ijesrr/V4-i11-13, Impact Factor: 5.825

IJCSRR@ 2021

www.ijesrr.org

Table 7. Response of intestinal morphology (lungs) of pigs treated with different level of fermented mungbean in the diet.

\begin{tabular}{|c|c|c|c|}
\hline \multirow[b]{2}{*}{ Treatment } & \multicolumn{3}{|l|}{ Lungs } \\
\hline & Length (in cm) & Width (in cm) & Weight (in kg) \\
\hline $\mathrm{T}_{1}$ & 16 & 9 & 320 grams \\
\hline $\mathrm{T}_{2}$ & 26.6 & 11 & 350 grams \\
\hline $\mathrm{T}_{3}$ & 15.6 & 8 & 300 grams \\
\hline R square & .001 & .107 & .158 \\
\hline p-value & .980 & .788 & .740 \\
\hline $\mathrm{F}$ & .001 & .120 & .188 \\
\hline \multicolumn{4}{|c|}{ Unstandardized Coefficients: } \\
\hline (Constant) & 19.800 & 10.333 & 343.333 \\
\hline Treatment & -.200 & -.500 & -10.000 \\
\hline \multicolumn{4}{|c|}{$95.0 \%$ Confidence interval for B: } \\
\hline Lower bound & -79.428 & -18.840 & -303.437 \\
\hline Upper bound & 79.028 & 17.840 & 283.437 \\
\hline Interpretation & Not Significant & Not Significant & Not Significant \\
\hline
\end{tabular}

Gleaned on Table 8, the response of intestinal morphology of pigs in relation to esophagus treated with different level of fermented mungbean in the diet. As seen on the table, the coefficient determination of r-square ( $\mathrm{r} 2$ ) is 0.107 on length, width is 0.000 and weight of esophagus is 0.077 . This states that a dropped to zero of $\mathrm{r} 2$ on the width of the esophagus means that $0 \%$ indicates no linear relation under the different treatment. However, $10.7 \%$ of the variations on the length and $7.7 \%$ on the weight of the esophagus are expressed on the different level of treatment. The $95 \%$ confidence interval in the length of the esophagus is somewhere -9.420 and 8.920 on length, width is +7.336 and weight is somewhere -450.156 and 430.156 . This indicates that, for every treatment the pig's intake, the estimated average cost of the weight of the esophagus spent is somewhere in between Php450.156 and 430.156. At the significance level of 5\%, the length, width and weight of the esophagus had no variations as shown by its p-value $>0.050$. Therefore, the null hypothesis is accepted. From the above coefficients, the regression equation can be computed as, length of esophagus $=16.667-0.250$ (treatment), width $=6.333+0.000$ (treatment) and weight $=230.000-10.000$ (treatment). The result of analysis on the different treatment emphasize that, Treatment 2 obtained the highest weight of 250 grams treated with 500 grams of commercial feeds and 250 grams of mungbean meal and fermented mungbean while a light decrease of 20 grams was found on Treatment 1 and Treatment 2 with a total weight of 200 grams and 180 grams respectively. This only shows that Treatment 2 is good predictors of the growth performance of pigs. The slight difference in the weight of esophagus is attributed to the shortest treatment of native pigs. The effects of Bacillus subtilis fermented soybean meal (FSBM) on intestinal morphology and digestive enzyme activities in piglets had a higher $(\mathrm{P}<0.05)$ villus height at three different locations of small intestine and had a lower $(\mathrm{P}<0.05)$ crypt depth in the duodenum compared to piglets fed Soybean Meal (Feng et al.,2007). The results showed that activities of total protease and trypsin at the duodenum and jejunum of piglets fed with Fermented Soybean Meal increased $(\mathrm{P}<0.05)$ compared with the control. The trypsin activity in the pancreas of piglets decreased $(\mathrm{P}<0.05)$ when they were fed with fermented soybean meal

Table 8. Response of intestinal morphology (esophagus) of pigs treated with different level of fermented mungbean in the diet.

\begin{tabular}{llll}
\hline \hline & \multicolumn{3}{c}{ Esophagus } \\
\cline { 2 - 4 } Treatment & Length (in cm) & Width (in cm) & Weight (in $\mathrm{kg})$ \\
\hline $\mathrm{T}_{1}$ & 16 & 6 & 200 grams \\
$\mathrm{T}_{2}$ & 17 & 7 & 250 grams \\
$\mathrm{T}_{3}$ & 15.5 & 6 & 180 grams \\
\hline R square & .107 & .000 & .077 \\
$\mathrm{p}$-value & .788 & 1.000 & .821 \\
$\mathrm{~F}$ & .120 & .000 & .083 \\
\hline \hline
\end{tabular}




\section{International Journal of Current Science Research and Review}

ISSN: 2581-8341

Volume 04 Issue 11 November 2021

DOI: 10.47191/ijesrr/V4-i11-13, Impact Factor: 5.825

IJCSRR@ 2021

www.ijesrr.org

\begin{tabular}{ccll}
\hline \hline \multicolumn{2}{l}{ Unstandardized Coefficients: } & & \\
(constant) & 16.667 & 6.333 & 230.000 \\
Treatment & -.250 & .000 & -10.000 \\
95.0\% Confidence interval for B: & & \\
Lower bound & -9.420 & -7.336 & -450.156 \\
Upper bound & 8.920 & 7.336 & 430.156 \\
\hline Interpretation & Not Significant & Not significant & Not Significant \\
\hline \hline
\end{tabular}

It is represented on Table 9, the response of intestinal morphology of pigs in terms of spleen treated with different level of fermented mungbean in the diet. As gleaned on the table, the coefficient determination of r-square (r2) is 0.250 on the length, width is 0.000 and weight of spleen of pigs is 0.058 . This indicates that $25 \%$ of the variation of length and $5.8 \%$ of the weight of the pigs is explained by the different level of treatment, while a dropped to zero of $\mathrm{r} 2$ indicates that there is no linear relation on the width of the spleen under the different level of treatment. The 95\% confidence interval in the length of the spleen is somewhere -11.504 and 10504 , the width is +7.336 , and weight is somewhere -261.758 and 251.758 . This indicates that, for every treatment the pig's intake, the estimated average cost of the weight of the spleen spent is somewhere in between Php261.758 and Php251.578. At the significance level of $5 \%$, the length $(\mathrm{p}$-value $=.667)$, width $(\mathrm{p}$-value $=1.000)$ and weight $(\mathrm{p}$-value $=.846)$ of the spleen has no variations as shown by its p-value $>0.050$. Therefore, the null hypothesis is accepted. From the above coefficients, the regression equation can be computed as, length of spleen $=19.000-0.500$ (treatment), width $=5.333+0.000$ (treatment) and weight $=86.667$ - 5.000 (treatment). The result of treatment further observed that, Treatment 2 has the highest spleen weight of 100 grams which is treated with 500 grams commercial feeds and 250 grams of both mungbean meal and fermented mungbean, while Treatment 1 and 3 using 100\% commercial feeds and 500 grams commercial feeds, 300 grams mungben meal and 200 grams fermented mungbean respectively, have the same total spleen weight of 70 grams. This only shows that Treatment 2 despite of the slight variations on the spleen weight is good predictors of the pig's growth performance. Feeding diets containing 19\%-23\% crude protein could help meet the growth needs of weaning piglets (Wu et al., 2015). It is important therefore to determine whether the performance and intestinal health would be affected in piglets if dietary crude protein is increased from $17.3 \%$ without in-feed antibiotics. In addition, weaned piglets fed animal protein sources appear to have a superior feeding value than plant sources, which partly due to the plant proteins are less digestible than animal proteins.

Table 9. Response of intestinal morphology (spleen) of pigs treated with different level of fermented mungbean in the diet.

\begin{tabular}{|c|c|c|c|}
\hline \multirow[b]{2}{*}{ Treatment } & \multicolumn{3}{|l|}{ Spleen } \\
\hline & $\begin{array}{l}\text { Length } \\
\text { (in } \mathrm{cm} \text { ) }\end{array}$ & $\begin{array}{l}\text { Width } \\
\text { (in } \mathrm{cm} \text { ) }\end{array}$ & $\begin{array}{l}\text { Weight } \\
\text { (in kg) }\end{array}$ \\
\hline $\mathrm{T}_{1}$ & 17 & 5 & 70 grams \\
\hline $\mathrm{T}_{2}$ & 18 & 6 & 100 grams \\
\hline $\mathrm{T}_{3}$ & 17 & 5 & 70 grams \\
\hline R square & .250 & .000 & .058 \\
\hline p-value & .667 & 1.000 & .846 \\
\hline $\mathrm{F}$ & .333 & .000 & .061 \\
\hline \multicolumn{4}{|c|}{ Unstandardized Coefficients: } \\
\hline (Constant) & 19.000 & 5.333 & 86.667 \\
\hline Treatment & -.500 & .000 & -5.000 \\
\hline \multicolumn{4}{|c|}{$95.0 \%$ confidence Interval for B: } \\
\hline Lower bound & -11.504 & -7.336 & -261.758 \\
\hline Upper bound & 10.504 & 7.336 & 251.758 \\
\hline Interpretation & Not Significant & Not Significant & Not Significant \\
\hline
\end{tabular}




\section{International Journal of Current Science Research and Review}

ISSN: 2581-8341

Volume 04 Issue 11 November 2021

DOI: 10.47191/ijcsrr/V4-i11-13, Impact Factor: 5.825

It is presented on Table 10, the response of intestinal morphology of pigs in terms of kidney treated with different level of fermented mungbean in the diet. As shown on the table, the coefficient determination of $r$-square $\left(r^{2}\right)$ is 0.000 on the length, width and weight of kidney of the pigs. A dropped to zero of $\mathrm{r}^{2}$ indicates that there is no linear relation on the length, width and weight of kidney under the different level of treatment. The $95 \%$ confidence interval in the length of the heart is somewhere \pm 7.336 , width is \pm 7.336 , and weight is somewhere \pm 733.593 . This indicates that, for every treatment the pig's intake, the estimated average cost of the weight of the kidney spent is somewhere Php733.593. At the significance level of 5\%, the length, width and weight of the kidney had no variations as shown by its p-value $>0.050$ which is 1.000 . Therefore, the null hypothesis is accepted. From the above coefficients, the regression equation can be computed as, length of kidney $=10.333+0.000$ (treatment), width $=6.333+0.000$ (treatment) and weight $=183.333+0.000$ (treatment). As a result of the analysis it is observed that using 500 grams of commercial feeds, 250 grams mungbean meal and 250 grams of fermented mungbean for Treatment 2 can obtained a total weight of 250 grams for kidney while using Treatment 1 and 3 can only have a weight of 150 grams. This shows that, Treatment 2 greatly affect the growth performance of pig. According to Lee et al, 2016, with the slight difference on the weight advantage of using polyphenol content as a feed supplement, mungbean coat needs to be treated to release its antioxidant compound. Moreover, the number of antioxidants should be sufficient to promote the immune capabilities of pigs, as in natural form, it has no extra value as roughage. It has suggested that antioxidant and anti-inflammatory properties of mungbean coats can be greatly increased once fermented with fungi.

Table 10. Response of intestinal morphology (kidney) of pigs treated with different level of fermented mungbean in the diet.

\begin{tabular}{|c|c|c|c|}
\hline & Kidney & & \\
\hline Treatment & $\begin{array}{l}\text { Length } \\
\text { (in } \mathrm{cm} \text { ) }\end{array}$ & $\begin{array}{l}\text { Width } \\
\text { (in } \mathrm{cm} \text { ) }\end{array}$ & $\begin{array}{l}\text { Weight } \\
\text { (in kg) }\end{array}$ \\
\hline $\mathrm{T}_{1}$ & 10 & 6 & 150 grams \\
\hline $\mathrm{T}_{2}$ & 11 & 7 & 250 grams \\
\hline $\mathrm{T}_{3}$ & 10 & 6 & 150 grams \\
\hline $\mathrm{R}$ square & .000 & .000 & .000 \\
\hline p-value & 1.000 & 1.000 & 1.000 \\
\hline $\mathrm{F}$ & .000 & .000 & .000 \\
\hline \multicolumn{4}{|c|}{ Unstandardized Coefficients: } \\
\hline (Constant) & 10.333 & 6.333 & 183.333 \\
\hline Treatment & .000 & .000 & .000 \\
\hline \multicolumn{4}{|c|}{ 95.0\% Confidence interval for B: } \\
\hline Lower bound & -7.336 & -7.336 & -733.593 \\
\hline Upper bound & 7.336 & 7.336 & 733.593 \\
\hline Interpretation & Not Significant & Not Significant & Not Significant \\
\hline
\end{tabular}

Table 11 represents the treatment that gives good output to the growth performance of pigs treated with different levels of fermented mungbean in the diet using feed conversion efficiency. As shown on the table, the lowest feed conversion efficiency is obtained by Treatment 2 with food conversion efficiency of 3.89 on feeds and 1.39 on mungbean. This means that, it took 3.89 kilos of feeds and 1.39 kilos of mungbean to produce one (1) kilo of meat. However, Treatment 1 has the highest feed conversion efficiency of 9.33 on feeds and zero on mungbean. This indicates that, it took 9.33 kilos of feeds to produce one (1) kilo of meat. The result of analysis shows that Treatment 2 gives good output to the growth performance of pigs. Thus, the lower the feed conversion efficiency, the lower the cost of rearing pigs the greater the income. ${ }^{3}$ Growth of pigs, protein source is very important factor for nursery pig's growth, because poor amino acid and protein nutrition have a profound effect on physiology health status and growth factor of pigs. Diets with high crude protein content are commonly used for early-weaned pigs. This kind of diet can improve growth performance of piglets, but is always associated with incidence of diarrhea. Proteins are composed of amino acids, and it is actually the amino acids that are the essential nutrients. 


\section{International Journal of Current Science Research and Review}

ISSN: 2581-8341

Volume 04 Issue 11 November 2021

DOI: 10.47191/ijcsrr/V4-i11-13, Impact Factor: 5.825

IJCSRR @ 2021

www.ijesrr.org

Table 11. Feed conversion efficiency of pigs treated with different levels of feeding regimen.

\begin{tabular}{|l|l|l|l|l|l|l|l|}
\hline Treatment & \multicolumn{2}{|l|}{ Body weight } & \multicolumn{2}{l|}{ Feed Consumption } & \multicolumn{2}{l|}{$\begin{array}{l}\text { Feed } \\
\text { Efficiency (FC/TGW) }\end{array}$} \\
\cline { 2 - 8 } & $\begin{array}{l}\text { Initial } \\
\text { body } \\
\text { weight } \\
\text { (in kg) }\end{array}$ & $\begin{array}{l}\text { Final body } \\
\text { weight } \\
\text { (in kg) }\end{array}$ & $\begin{array}{l}\text { Total } \\
\text { gain } \\
\text { weight } \\
\text { (in kg) }\end{array}$ & Feeds & Mungbean & Feeds & Mungbean \\
\hline & & & & & & & \\
\hline $\mathrm{T}_{1}$ & 20.50 & 28.00 & 7.50 & 70 & - & & \\
\hline $\mathrm{T}_{2}$ & 21.00 & 30.00 & 9.00 & 35 & 12.50 & 3.89 & 1.39 \\
\hline $\mathrm{T}_{3}$ & 20.50 & 27.00 & 6.00 & 35 & 12.50 & 5.83 & 2.08 \\
\hline
\end{tabular}

\section{CONCLUSIONS}

From the summary of findings, the researcher concluded that: Treatment 2 has the highest gain weight among the treated sample. The intestinal morphology of pigs was comparably observed under the three treatments. Hence, the null hypothesis is accepted. Treatment 2 with the lowest feed conversion efficiency is a good output.

\section{RECOMMENDATIONS}

Highly application of systematic Treatment 2 could be adopted to improve the growth performance of pigs, gut morphology, meat qualities, better feed conversion efficiency and profit. The no variations in the study could be used to develop other treatment on mungbean coat to release its antioxidant compound to promote the immune capabilities of pigs. Fermentation of mungbean is recommended to promote the healthy bacteria in the intestinal tract of pigs. This study may be conducted by other researchers in educational institutions and government agencies public or private by conducting researches related to the study.

\section{REFERENCES}

1. Baguio, Synan S. 2017. R\&D activities to improve native pig production. Officer-in-Charge, Livestock Research Division, DOST-PCAARD S\&T Media Service, p. 1.

2. Biagi, G.; Piva, A.; Moschini, M.; Vezzali, E. and Roth, F. X. 2007. Performance, intestinal microflora, and wall morphology of weanling pigs fed sodium butyrate. Journal of Animal Science, 85 (5): 1184-1191.

https://doi.org/10.2527/jas.2006-378,

3. Bindas, Lubor; Maskalova, Iveta; and Bujnak, Lukas. 2015.. The effect of protein metabolism on weanling blood parameters level. Acta fytotech. Zootechn., 3:76-78,

4. Campbell, Joy M., Creshaw, Joe D., and Polo, Javier. 2013. The Biological stress of early weaned piglets. Journal of Animal Science and Biotechnology, 4:19.

5. Celi, P.; Cowieson, A. J.; Fru-nji, F.; Steinert, R.E.; Kluenter, A.M.; Verlhac, V. 2017. Gastrointestinal functionality in animal nutrition and health: New opportunities for sustainable animal production. Animal Feed Science and Technology, 234: 88-100,

6. Feng, J; Liu, X; Xu, ZR; Lu, YP; and Liu Y.Y. 2007. Effect of fermented soybean meal on intestinal morphology and digestive enzyme activities in weaned piglets,52 (8): 1845-50.

7. Gan, Ren-You, Li, Hua-Bin, Gunaratne, Anil, Sui, Zhong-Quan, and Corke, Harold. 2017. Effects of fermented edible seeds and their products on human health: Bioactive Components and Bioactivities. Comprehensive Reviews in food Science and Food Safety, 00 (1): 1-41,

8. Gao, Y., Han, F., Huang, X., Rong, Y., Yi, H., and Wang Y. 2013. Changes In gut microbial populations, intestinal morphology, expression of tight junction proteins, and cytokine production between two pig breeds after challenge with Escherichia coli K88: A comparative study. Journal of Animal Science 91:5614-5625. 


\section{International Journal of Current Science Research and Review}

ISSN: 2581-8341

Volume 04 Issue 11 November 2021

DOI: 10.47191/ijesrr/V4-i11-13, Impact Factor: 5.825

IJCSRR@ 2021

www.ijcsrr.org

9. Wu, Han, Rui, Xin, Li, Wei, Chen, Xiaohong, Jiang, Mei and Dong, Mingseng. 2015. Mungbean (Vigna radiata) as probiotic food through fermentation with Lactobacillus plantarum B1-6. Food Science and Technology, 63, 445-451.

10. Hedemann, M. S.; Eskildsen, M.; Lærke, H. N.; Pedersen, C.; Lindberg, L. E.; Laurinen, P. and Knudsen, Bach K.E. 2006. Intestinal morphology and enzymatic activity in newly weaned pigs fed contrasting fiber concentrations and fiber properties. Journal of Animal Science. Retrieved from http://jas.fass.org/cgi/content/full/84/6/1375,

11. Lee, D.N., Hung, Y. S., Yang, T. S., Lin, J.H., and Weng, C.F. 2016. Aspergillus awamori-fermented mungbean seed coats enhance the antioxidant and immune responses of weaned pigs. Journal of Animal Physiology and Animal Nutrition, 1-2.

12. Liao, Shenfa F. and Nyachoti, Martin. 2017. Using probiotics to improve swine gut health and nutrient utilization. Animal Nutrition 3: 331-343.

13. Missoten, Joris A.M.; Michiels, Joris; Degroote, Joreon and De Smet, Stefaan. 2015. Fermented Liquid Feed for Pigs: An Ancient Technique for the Future. Journal of Animal Science and Biotechnology, 6:4., Retrieved from http://www.jasbsci.com/content/6/1/4

14. Moore, R.J., Kornegay, E.T., Grayson, R.L., and Lindemann, M.D. 1988. Growth, Nutrient Utilization and Intestinal Morphology of Pigs Fed High-Fiber Diets. Journal of Animal Science, 66 (6): 1570-1579.

15. Nathania, Illona; Sugih, Asaf Kleopas, and Muljana, Henk. 2017. Preliminary Study on the Synthesis of Phosphorylated Mung Bean Starch: The Effect of pH on the Physicochemical and Functional Properties. Indones. J. Chem., 17 (3): 401 406.

16. Paras, Edrian P., and Cu-Cordoves, Rodeza Kristine. 2014. Estimating Liveweight of Philippine native pigs using external body measurements. Phillip J Vet Anim, 40:47-52.

17. Tossou, Myrlene Carine B., Liu, Hongnan, Bai, Miamiao. 2016. Effect of High Dietary Tryptophan on Intestinal Morphology and Tight Junction Protein of Weaned Pig. BioMed Research International ID 29122418.

Cite this Article: Ken N Falculan Ph.D. (2021). Digestive Morphology of Native Pig Supplemented by Different Levels of Fermented Vigna radiata L. International Journal of Current Science Research and Review, 4(11), 1572-1584 